\title{
Comment on: Effects of hydroxyurea on brain function in children with sickle cell anemia
}

\author{
Anees Ahmed ${ }^{1}$, Ahmed hayat ${ }^{1}$, and Hamood Ur Rehman Chaudhry ${ }^{1}$ \\ ${ }^{1}$ Punjab Medical College
}

February 9, 2022

\section{Hosted file}

Anees work.docx available at https://authorea.com/users/459705/articles/555888-comment-oneffects-of-hydroxyurea-on-brain-function-in-children-with-sickle-cell-anemia 